\title{
A SEDIMENTAÇÃO DO GRUPO PASSA DOIS (EXCLUSIVE FORMAÇÃO ORATI): UM MODELO GEOMÓRFICO
}

\author{
ERCÍLIO GAMA JR. \\ INSTITUTO DE GEOCIÊNCIAS E CIÊNCIAS EXATAS UNESP — RIO CLARO
}

\begin{abstract}
Regional investigation of the Passa Dois Group of the Parana Basin, excluded Irati Formation using outcrop and subsurface data indicates three principal depositional systems: (1) a high destructive tide dominated delta system designated Serra do Espigão Delta Sys. tem; (2) the Corumbatai tidal flat System developed in the northeastern of São Paulo State; and (3) the Serra Alta epeineritic shelf System.
\end{abstract}

The Serra do Espigão Delta System is te dominant element in the Santa Catarina and Paraná States and comprises

O objetivo principal do presente trabalho é realizar uma análise faciológica dos sedimentos do Grupo Passa Dois, exclusive Formação Irati, e elaborar, com base em analogia com províncias de sedimentação moderna, um modelo deposicional| traduzido em termos geomórficos.

O Grupo Passa Dois constitui o topo da sequiência paleozóica da Bacia do Paraná. De idade permiana superior inclui as formações Irati, Estrada Nova e Rio do Rastro que, em conjunto, atingem a mais de 1200 metros de espessura. Embora seja uma das sequiências sedimentares bem investigada da bacia, com seus processos sedimentares bem definidos, pairam ainda controvérsias quanto ao seu provável ambiente de sedimentação.

0 reconhecimento de modelos de sedimentação não encerra somente um interesse acadêmico, relacionado com a compreensão dos mecanismos físicos, químicos e biológicos ocorridos durante a evolução histórica de uma região da Terra. Tal informação é de fundamental importância na exploração dos recursos naturais geneticamente associados à certos ambientes específicos. Um modelo correto, que possibilite compa-

\begin{abstract}
several deltas developed throughout the Upper Permian. Vertical sequence grades upward from Terezina prodelta muds through Serrinha delta front sands into fluvial sands and muds of the Morro Pelado delta plain. Such succession reflects regression and progradation of the system. Sediments were derived from South of Mato Grosso State carried by low gradient retilineous rivers. The deltas prograded from West to East over a shallow epicontinental sea opened at East in which was developed the muds of the extensive Serra Alta Shelf System. Prograding
\end{abstract}

from north to south into the furthest end of the Serra Alta gulf a tidal flat was developed, behind of the Serra do Espigão deltas, supplied by longshore drift of sediments from the delta system.

Principal features of the main depositional systems are shown in strike and dip stratigraphic sections and in isolith and distribution maps. These illustrate the relationship of the major systems and their constituent facies and also define the sedimentation geomorphic model of the Passa Dois Group.

\section{INTRODUÇÃO}

racões com equivalentes geologicamente bem conhecidos, pode mesmo constituir-se em um importante passo na previsão de ocorrência daqueles recursos e, consequentemente, numa pesquisa e exploração mais racional.

A reconstrução ambiental, entretanto, apresenta uma dificuldade básica relacionada com a natureza artificial das unidades litoestratigraficas. Estas, por serem definidas baseadas em critérios operacionais de mapeamento, não representam, necessariamente, unidades genéticas. Formações em contato concordante reunem sedimentos de uma mesma ou de províncias geomorficas adjacentes. A não compreensão exata da extensão deste fato, acredita-se, seja a principal causa das controvérsias sobre ambientes de sedimentação, pois ao se restringir uma análise paleoambiental a linhas ou superficies artificiais secciona-se a natural sucessão vertical de facies que reflete a distribuição horizontal dos ambientes (Walther, 1894).

No presente trabalho, as unidades litostratigraficas do Grupo Passa Dois foram relegadas a segundo plano, sendo substituídas pelos sistemas deposicionais (Fisher e McGowen, 1967). Estes foram definidos por critérios genéti- cos a partir das fácies sedimentares identificadas em afloramentos do Paraná, Santa Catarina e São Paulo. O controle de sub-superficie implicou em seus reconhecimentos nos perfís elétricos de 32 poços de petróleo e confeccão de doze seções estratigráficas através de toda a bacia (fig. 1). Mapas de isópacas e isólitas de arenitos e análises de tendência destas variáveis completaram os elementos básicos para a interpretação final e elaboração do modelo de sedimentação.

Embora pertença a mesma sequiência sedimentar Gama (Soares et al., 1974), os sedimentos Irati foram excluidos da presente análise pelo fato de representar um estádio de transição enre dois ciclos de sedimentação clástica, ou sẹja, o sotoposto Grupo Tubarão e a seqüência objeto da presente análise.

Agradecimentos especiais são dirigidos ao Conselho Nacional de Pesquisa

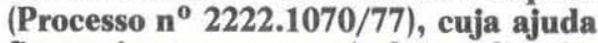
financeira tornou possível a realização deste trabalho. 0 Autor estende seus agradecimentos as colegas Paulo M.B. Landim, Paulo C. Soares e Vicente J. Fúlfaro pelas críticas e sugestões oferecidas. 


\section{FÁCIES SEDIMENTARES}

$\mathrm{Na}$ faixa de afloramentos do Grupo Passa Dois identificou-se sete fácies, cujas possanças, características ou abundância relativa quando associadas, permitiram seu reconhecimento nos perfis elétricos dos poços profundos da bacia.

A fim de evitar uma desnecessária sinonímia, utilizou-se, na designação destas fácies, os termos formais litoestratigráficos correspondentes. Tal procedimento não implica, necessariamente, em equivalência de unidades.

Nos estados do Paraná e Santa Catarina a seqüência em estudo é constituida por seis unidades, cujo perfil vertical acha-se esquematizado na figura 2.

\subsection{Fácies de Lamitos Pretos Serra Alta}

Caracterizada por argilitos, folhelhos e siltitos cinza escuros a pretos com incipiente laminação paralela e restos de peixes, palecípodos, conchostráceos e palinomorfos. Concreçðes calcíferas muito ricas em fósseis (Mendes, 1967) é seu especto mais característico. Apresenta grande persistência lateral na base da seqüência estudada, estando presente em todos os poços da bacia, a excessão de alguns do sul do Mato Grosso. Seu contato com os sedimentos que se lhe sobrepðem é concordante registrando-se, eventualmente, mútuas intercalações ou recorrências.

$O$ processo sedimentar inferido para esta fácies relaciona-se com a deposiçåo de partículas em suspensão em águas marinhas suficientemente profundas para abrigar seus depósitos da ação de ondas, correntes ou oxidação. Como anteriormente observado por outros autores (Northfleet et al., 1969; Mülhmann et al., 1974), reflete um ambiente marinho de baixa energia.

\subsection{Fácies de Lamitos Cinza Terezina}

Caracterizada pela alternância em finas lâminas de folhelho cinza escuro ou esverdeado e siltito cinza claro, com mal desenvolvida laminação paralela que freqüentemente passa a lenticular ou "flazer". Marcas onduladas e estratificação cruzada de pequena escala nas camadas sílticas são outras estruturas sedimentares presentes. O conteúdo fossilífero inclui lamelibrânquios, restos de plantas e palinomorfos (Daemon e Quadros, 1969).

Em subsuperfície, esta fácies apresenta uma grande variação de espessura com maior desenvolvimento nos esta- dos do Paraná e Santa Catarina, acunhando-se paulatinamente em direção ao sul e ao norte. Em São Paulo interdigita-se com a fácies de lamitos arroxeados Corumbataí, culminando por se ausentar em sua faixa de afloramentos. Embora seja a constituinte principal da formação homônima, esta fácies achase presente também no Membro Serrinha da Formação Rio do Rasto, preferencialmente em sua metade inferior.

Suas características internas evidenciam dois processos sedimentares associados: decantação de partículas em suspensão e correntes de maré em condições marinhas de inframaré. A presença de restos vegetais e outros fósseis atribuidos como de água doce denuncia uma influência fluvial, indicando proximidade de desembocaduras de rios. Em suma, processos sedimentares perfeitamente compatíveis com ambiente marinho relativamente mais raso mas, ainda, permanentemente subaquoso conforme preconizado por diversos autores (Mendes e Fúlfaro, 1966; Fúlfaro, 1971).

\subsection{Fácies de Arenitos Esverdeados Serrinha}

Com ocorrência limitada à faixa de afloramentos do Paraná e Santa Catarina e poços da região que se estende do norte do Rio Grande do Sul a sudoeste de São Paulo e sul de Mato Grosso, esta fácies é caracterizada por arenitos muito finos, bem selecionados, esverdeados, texturalmente maturos, com estratificação horizontal a cruzada de baixo ângulo; subordinadamente ocorrem estratificação cruzada sigmoidal e marcas onduladas.

Em subsuperfície se apresenta como corpos lenticulares intercalados em sedimentos da fácies de lamitos cinzas. A frequiência destas intercalações determina o contato entre a Formação Teresina e o Membro Serrinha da Formação Rio do Rasto, sendo escassas na primeira e predominantes no último.

$\mathrm{O}$ processo sendimentar envolvido em sua deposição resulta da ação de correntes de maré em condições de intermaré e posterior lavagem por ondas e correntes litorâneas. Estas condições hidrodinâmicas, características de regið̃es litorâneas (Fúlfaro, 1971), são responsáveis pelas estruturas sedimentares presentes bem como pela boa seleção destes sedimentos.

\subsection{Fácies de Calcários Biodetriticos}

Caracterizada por calcários cinza a creme, microcristalinos, por vezes oolíticos, contendo, eventualmente intra- clastos e bioclastos de fragmentos de conchas. Intercalados em sedimentos das fácies de lamitos cinzas e de lamitos arroxeados, sua ocorrência é detectada nas duas faixas de afloramentos e em todos os poços da bacia. Em Săo Paulo são descritas estruturas estromatolíticas e no Rio Grande do Sul estruturas tipo "cone-in-cone". Em superfície encontram-se frequentemente silicificados por processos pós-diagenéticos de natureza intempérica Recente ou préMesozóica (Landim, 1967).

Em subsuperfície se apresentam como corpos tabulares, pouco espessos e persistentes por grandes áreas, definindo excelentes camadas-chave de correlação.

Suas características evidenciam uma deposição em condições marinhas de infra e intermaré em áreas de pouco afluxo de terrígenos, o que permite o desenvolvimento de colônias algálicas e afins responsáveis pela produção dos bioclastos e intraclastos; em regiões dominadas por processos de intermaré, como enfatizado por Soares (1972), desenvolver-se-iam as estruturas estromalíticas.

\subsection{Fácies de Lamitos Avermelhados Morro Pelado}

Com sua ocorrência em superfície limitada a faixa de afloramentos do $\mathrm{Pa}$ raná e Santa Catarina e, em subsuperfície, aos poços perfurados nestes, e regiões fronteiriças dos estados adjacentes, está fácies é caracterizada por argilitos e siltitos avermelhados com laminação horizontal mal desenvolvida. $\mathrm{O}$ conteúdo fossilífero inclui vegetais e fauna de água doce, o que tem permitido aos diversos autores interpretá-la como depositada em ambiente continental fluvial.

Os processos sedimentares responsáveis pela sua gênese decorrem de transbordamentos de canais fluviais durante enchentes. Os sedimentos carreados para fora do canal são provenientes da carga-suspensa dos rios, siltes e argilas, que se depositam pela perda da competência das águas em áreas não confinadas. A contínua exposição entre sucessivas enchentes terminam por oxidálos, conferindo-lhes suas cores avermelhadas.

Esta fácies se faz presente tanto no membro homônimo como na parte superior do Membro Serrinha da Formação Rio do Rasto.

\subsection{Fáceis de Arenitos Lenticulares Morro Pelado}

Intercalados nos sedimentos da fácies anterior e, consequientemente, com a mesma área de ocorrência, esta fácies é 
caracterizada por arenitos avermelhados, arroxeados, amarelados, esbranquiçados, de granulação fina a média, texturalmente imaturos a submaturos, ricos em estratificação horizontal e cruzada acanalada. Acunhamentos de camadas e lenticularidade de corpos arenosos são feições bastante frequentes.

Estas características indicam que estes sedimentos resultam de processos sedimentares fluviais envolvendo correntes confinadas em canais e, durante enchentes, em áreas não confinadas. A variação textural e tipo de estratificação decorrem da variação dos regimes de fluxo.

\subsection{Fáceis de I amitos Arroxeados Corumbataí}

A Fácies de Lamitos Arroxeados tem sua ocorrência limitada a regiåo norte $\mathrm{e}$ nordeste de São Faulo e sul de Goiás. E caracterizada por siltitos e folhelhos arroxeados e avermelhados, com laminação parzlela mostrando frequentemente estruturas "flazer" e fendas de ressecamento. Estratificação cruzada de pequeno porte e marcas onduladas tem sido igualmente descritas em seus afloramentos (Landim, 1967).

Em subsuperfície, esta fácies se interdigita com os lamitos cinza e arenitos esverdeados na região central do Estado de São Paulo.

No poço OL-1-SP (Olímpia) os sedimentos da fáceis de lamitos cinzas se assentam sobre os lamitos arroxeados, após uma zona de transição com alternâncias de ambas as fácies.

Para o norte, em direção a Goiás não se tem nenhum controle de sua extensão ou variação lateral.

Suas características internas indicam deposição em condições litorâneas sob o domínio de correntes de maré.Intercalações desta com os calcários biodetríticos evidenciam variações de suprimento terrígeno que quando ausente, permitem o desenvolvimento de colônias algálicas.

A principal diferença genética entre a fácies de lamitos cinza e de lamitos arroxeados reside na profundidade de lâmina d'água e natureza do suprimento terrígeno. Em ambos, o processo sedimentar dominante é o mesmo: correntes de maré. Entretanto, na primeira as correntes de maré atuam em áreas permanentemente cobertas por água (infra-maré) e nas proximidades de desembocaduras de rios. Na segunda, as correntes atuam em regióes de águas rasas (inter-maré) e relativamente afastadas das principais fontes de suprimento terrígeno; para estas, as correntes de maré desempenham também a ação de transporte.

\section{SISTEMAS DEPOSICIONAIS}

A interpretação ambiental no presente trabalho é feita através de duas linhas de raciocício convergente. A primeira de natureza dedutiva inclui:

a. evidências obtidas no estudo dos afioramentos e relacionadas com as características internas, relaçð̃es de contato, sucessão vertical e processos sedimentares invocados para a deposição de cada fácies.

b. evidências relacionadas com a distribuição, geometria, associação de fácies e relações tridimensionais obtidas em seções estratigráficas através de toda a bacia, das quais duas aqui apresentadas.

c. evidências extraídas de mapas de isolitas de arenitos e análise de tendência de espessuras de unidades genéticas.

A segunda linha de raciocínio, de natureza indutiva, decorre da analogia com as modernas províncias geombrficas de sedimentação.

As fácies de lamitos cinza Terezina, arenitos esverdeados Serrinha, lamitos avermelhados e arenitos lenticulares Morro Pelado e os processos sedimentares inferidos para suas respectivas deposições - decantação de lamas em ambiente marinho de baixa energia, correntes de maré, correntes litorâneas, processos fluviais em canais e transbordamentos em planícies de inundação constituem um sistema deposicional análogo aos modernos deltas destrutivos dominados por marés. Neste sistema, ora designado Sistema Deltáico Serra do Espigão, as duas primeiras fácies são interpretadas como depósitos subaquosos de prodelta e frente deltáica respectivamente, tendo sido gerados em diversos ciclos de sedimentação; as fácies de lamitos avermelhados e arenitos lenticulares Morro Pelado constituem a sedimentação fluvial de planície deltáica.

A fácies de lamitos arroxeados de Săo Paulo e seu respectivo processo sedimentar, correntes de maré, é interpretada como única constituinte de um sistema deposicional de planície de maré, aqui designado Corumbataí.

Finalmente, a fácies de lamitos pretos e seu processo sedimentar, decantação de partículas argilosas em ambiente marinho de baixa energia, é interpretada como constituinte de um sistema deposicional de plataforma, em condições epineríticas, aqui designado Sistema de Plataforma Epinerítica Serra Alta.

Estes três sistemas deposicionais, embora penecontemporâneos, assumiram importâncias variáveis na evolução da Bacia do Paraná durante o Permiano superior. A fácies de calcários biodetrí ticos é interpretada como unidade destrutiva, representando períodos de in- terrupção đa seđimentação terrígena. Depositada em condiçðes de plataforma rasa sem afluxo de terrígenos, esta unidade separa localmente os diversos ciclos deltáicos.

A nomenclatura dos sistemas deposicionais e de suas fácies componentes, aqui informalmente empregada, difere fundamentalmente da nomenclatura estratigráfica, em razão de sua natureza genética; não significa, entretanto, nenhuma modificação na terminologia formal.

\subsection{Sistema Deltáico Serra do Espigão}

O sistema deltáico Serra do Espigão é o sistema deposicional dominante do Grupo Passa Dois. Sua ocorrência é registrada em toda extensão da Bacia do Paraná, tanto em poços como em superfície, a exceção da metade nordeste do Estado de São Paulo e sua faixa de afloramentos. Igualmente, é duvidosa sua presença no extremo sudoeste da faixa de afloramentos do Rio Grande do Sul. Seu melhor desenvolvimento se dá na regiåo oeste do Estado do Paraná, registrando-sé sua espessura máxima no poço I-LS-1-PR (Laranjeiras do Sul, $\mathrm{n}^{\circ} 1$ ) onde atinge 1155 metros.

Sua sequencia subaquosa, prodelta Terezina e frente deltáca Serrinha, apresenta-se melhor desenvolvida segundo um eixo de maior subsidência situado no Paraná e orientado de oeste para leste, em direção ao atual Arco de Ponta Grossa (fig. 3). A seqüência continental, planície deltáica Morro Pelado, por sua vez, possui seu centro deposicional na região central do mesmo estado (Fig. 4).

A designação Serra do Espigão deriva do acidente geográfico de Santa Catarina onde as fácies deste sistema acham-se muito bem expostas em afloramentos bem conservados.

\subsubsection{Caracterização da natureza deltáica}

Um delta é definido como "um sistema deposicional litorâneo supride por um rio e que produz uma irregular progradação da linha de praia" (Fisher et al., 1969). Săo quatro, portanto, as condiçð̃es básicas de caracterização da natureza deltáica de uma seqüência sedimentar:

\section{a. deposição litorânea;}

b. natureza progradacional

c. que esta progradação seja irregular, isto é, de tal modo a produzir uma deflexão mar afora da linha de costa;

d. que esta seqüência tenha sido suprida por rios. 
As fácies de lamitos verdes Terezina, arenitos esverdeados Serrinha, arenitos lenticulares e lamitos avermelhados Morro Pelarlo satisfazem, em conjunto, estas condições, como será demostrado:

a. deposição litorânea: as características mais notáveis da fácies de arenitos esverdeados indicam a ação de ondas e correntes litorâneas como os processos sedimentares responsáveis pelo transporte e deposição de seus sedimentos. Tal fato tem levado os autores, de modo quase unânime, a interpretá-los, corretamente, como depósitos litorâneos (Fúlfaro et alii, 1978) ou de água rasas acima do nível base das ondas (Muhlmann, 1974; Northfleet et al., 1969).

Estudos recentes tem demonstrado que sedimentação terrígena em águas rasas não é tão uniforme e abundante como se preconizava até então; pelo contrário, é rara e excepcional, necessitando de condições hidrodinâmicas extremamente favoráveis para sua deposição (Reineck e Singh, 1973). Emery (1968) demonstrou que $70 \%$ de toda a plataforma continental moderna achase coberta por relíquias e somente $5 \%$ representa sedimentação terrígena moderna. Esta ocorre associada a províncias geomórficas litorâneas bem definidas: deltas, leques deltáicos, planícies de maré, planícies costeiras, complexos barreira-laguna e baías (Fisher e Brown, 1972). Em todas estas províncias a ação de ondas, correntes litorrâneas, correntes de maré e outros processos sedimentares marinhos impri mem, em maior ou menor grau, suas diagnósticas características nos sedimentos.

Em decorrência, tomando-se apenas as características internas das fácies. que são impressas pelos processos sedimentares, pode-se, tão somente, identificá-las como depósitos associados a uma das províncias geomórficas litorâneas, o que satisfaz a primeira condição básica de sedimentação deltáica, sem eliminar as demais possibilidades acima referidas.

b. natureza progradacional: progiadação ocorre quando o suprimento é maior que a subsidência resultando, em condições litorâneas, uma progressão dos ambientes continentais sobre os costeiros e estes sobre os subaquosos. Consequentemente, a seção colunar de um pacote de sedimentos depositados nestas condiçð̃es mostrará uma suces são vertical onde os depósitos subaquosos se situam na base e os continentais no topo, com os costeiros interpostos.

O perfil vertical de fácies do Grupo Passa Dois (fig. 2) mostra esta mesma sucessão, com a fácies de lamitos cinzas Terezina, interpretada como depositada abaixo do nível das ondas, na base do perfil sendo sobreposta pela fácies de arenitos esverdeados Serrinha, inter- pretada como depositada acima do nível de ação das ondas e, finalmente no topo, as subaéreas fácies de arenitos lenticulares e lamitos avermelhados Morro Pelado. Satisfeita, portanto, a segunda condição.

c. forma irregular da progradação: esta condição diz respeito a deflexão mar afora da linha de costa em deltas, derivando daí a própria designação desta província geomórfica. Em sedimentos antigos esta irregularidade é evidenciada peila configuração do mapa de isólitas de arenito do sistema progradante (fig. 5). Este mapa define o arcabouço deltáico posto que os arenitos, depositando-se preferencialmente ao longo da costa, retratam a área de maior persistência desse ambiente. Incluindo todos os sedimentos subaquosos da seqüência, o mapa de isólitas de arenito define uma geometria lobada com um eixo preferencial de deposição de arenitos situados no sul do Mato Grosso e com suas curvas fortemente orientadas de oeste para leste. Esta configuração evidencia a referida irregularidade na original linha da costa.

d. suprimento fluvial: o mapa de isólitas da sequêencia subaquosa, fácies lamitos cinzas Terezina e arenitos esverdeados Serrinha (fig. 5), e da sequiência continental, arenitos lenticulares e lamitos avermelhados Morro Pelado (fig. 6), definem sempre o mesmo eixo de suprimento de sedimentos, localizado na região sul do Mato Grosso. Considerando que a natureza concordante do contato entre estes dois grupos de fácies implica que seus ambientes eram adjacentes e penecontemporâneos (Walther, op. cit.) tem-se que a seqüência subaquosa foi suprida pela mesma drenagem da seqüência continental. Satisfeita, assim, a última condição básica de caracterização deltáica.

Embora estas condições sejam critérios fundamentais de identificação, as mais diagnósticas evidências de sedimentação deltáica provêm da composição, relações tridimensionais, sucessão horizontal e vertical das fácies que st passa a seguir abordar.

\subsubsection{Prodelta Terezina}

A fáceis de lamitos cinzas Terezinha é aqui interpretada como prodelta. Representa os primeiros sedimentos terrígenos introduzidos na bacia pelo avanço da sedimentação deltáica, sendo depositados inteiramente em condições subaquosas e abaixo do nível de ação de-ondas. Seus sedimentos, siltes e argilas, são provenientes da carga suspensa dos rios, cujo fluxo ao adentrar o reservatório marinho se dispersa segundo um jato plano superficial, ou seja, um fluxo hipopicnal (Bates, 1953); depositam-se, preferencialmente, em frente as desembocaduras dos principais distributários, gradando lateral e frontalmente para as argilas de plataforma Serra Alta. Correntes de maré, em condições de infra-maré, desempenharam importante papel no retrabalhamento e redistribuição destes sedimentos, como atesta a abundância de estruturas " flazer" nestes sedimentos. Este fato, aliado a diversidade de distributários e ciclos deltáicos terminaram por produzir um corpo sedimentar de generalizada extensão em toda a bacia.

\subsubsection{Frente Deltáica Serrinha}

A fácies de arenitos esverdeados Serrinha é aqui interpretada como frente deltáica. Representa os sedimentos arenosos transportados pelos rios como carga de fundo e depositados em condiçðes litorâneas em forma de barras de desembocadura. Ondas e correntes litorâneas são os agentes responsáveis pela lavagem destes sedimentos conferindoIhes a boa seleção, maturidade textural e estruturas sedimentares já descritas. Em distributários onde a energia marinha, em forma de correntes de maré, superou o volume de suprimento, estes sedimentos foram retrabalhados e redistribuidos em forma de barras de maré produzindo corpos arenosos alongados, depositados em condiçð̃es subaquosas e imersos em argilas prodeltáicas.

Embora as características texturais das barras de desembocadura e de maré sejam semelhantes, sua distinção é facilmente feita pelas :elações de contato com as demais fácies. As primeiras por se depositarem em condições litorâneas situam-se no topo da sequiência de sedimentos sur-aquosos sendo superpostos pela fácies fluviais da planície deltáica. Na coluna litoestratigráfica corresponde aos sedimentos da parte inferior do Membro Serrinha da Formação Rio do Rasto. As barras de maré, ao contrário, por se depositarem em areas afastadas da costa, constituem intercalações lenticulares e erráticas nas argilas prodeltáicas. Correspondem as intercalações arenosas da Formação Terezina. Em superfície, as barras de maré se apresentam como pequenas elevações constituidas de arenitos que se destacam em planícies argilosas da faixa de afloramentos da Formação Terezina.

O mapa de isólitas de arenito da seqüência subaquosa (fig. 5) define indubitavelmente a área fonte na regiåo sul de Mato Grosso, desenvolvendo-se os deltas em ciclos preferencialmente orientados para sudeste de Santa Catarina. Um eixo secundário de desenvolvimento situa-se ao norte do Paraná. orientado de oeste para leste. 
As seções estratigráficas ilustram melhor as relações tridimensionais das fácies. Aquelas foram construidas tomando-se como "datum" o contato da fácies de lamitos cinzas com a fácies de lamitos avermelhados, correspondendo grosseiramente ao contato dos membros Serrinha e Morro Pelado. Embora não seja um horizonte isócrono este "datum" separa os sedimentos subaquosos dos continentais. A seção estratigráfica $\Lambda A^{\circ}$ (fig. 7), orientada paralelamente a borda da bacia, secciona a sedimentação deltáica transversalmente. As barras de desembocadura, pela sua deposição litorânea, apresenta os depósitos dos inúmeros distribuitários dos diversos ciclos deltáicos imbricados, resultando corpos arenosos de grande extensão lateral. Situam-se; preferencialmente. na parte superior da seqüência subaquosa. As barras distais em oposição, constituem lentes arenosas alongadas, com dimensões da ordem de dezenas de quilômetros, desenvolvidas preferencialmente na região dos poços TP-2-SC (Três Pinheiros $n^{\circ}$ 2) e LS-1-PR (Laranjeiras do Sul no 1). O poço CM-1-PR (Campo Mourão no 1), por se situar entre os dois eixos preferenciais de desenvolvimento deltáico, é pobre em arenitos embora apresente a maior espessura de sedimentos subaquosos.

A seção estratigráfica BB' (fig. 8), por sua vez, acha-se orientada no sentido longitudinal à progradação deltáica, ou seja, paralelamente ao paleodeclive deposicional. O poço AM-1-MT (Amambaí, $\left.\mathrm{n}^{\circ} 1\right)$, situado próximo a fonte, é extremamente arenoso em sua seqüência subaquosa, sendo raras as argilas prodeltáicas. Mergulho abaixo, os arenitos se acunham contra as argilas que passam a predominar nos poços situados a sudeste. Ambas as seções se interceptam no poço LS-1-PR (Laranjeiras do Sụl, $n^{\circ} 1$ ) permitindo uma visão tridimensional da sedimentação deltáica.

\subsubsection{Planícic IDelláica Morro Pelado}

As fácies de arenitos lenticulares e lamitos avermelhados Morro Pelado são aqui int ərpretadas como depositadas na planície deltáica. A primeira representa predominantemente depósitos de canal enquanto a segunda, depósitos de planície de inundação.

As evidências de que esta sedimentação fluvial ocorreu em planície deltáica incluem:

a. abundância relativa da fácies argilosa relativamente a arenosa. Os lamitos avermelhados perfazem aproximadamente $50 \%$ dos sedimentos continentais, evidenciando uma planície fluvial senil com rios de muito baixo declive longitudinal e, consequentemente, ele- vada carga suspensa relativamente a carga de fundo.

b. a abundância de depósitos de canal de forma lenticular denuncia rios retilíneos relativamente estabilizados na planície fluvial.

c. abundância de depósitos de "crevasses splays", diques marginais bem desenvolvidos e canais abandonados evidencia rios com elevada descarga e frequentes transbordamentos.

A sidimentação fluvial é controlada por uma série de fatores: litologia e estrutura do substrato, relevo e clima são os fatores independentes que afetam a natureza da descarga, volume e calibre da carga sedimentar, declive, velocidade de fluxo, largura e profundidade dos canais. Diferentes combinações destes fatores se refletem na sedimentação fluvial pela composição e abundância relativa das fácies. No presente caso, as evidências acima citadas permitem classificar a sedimentação flut vial Morro Pelado como de distributário deltáico (Fisher e Scott, inédito; Gama Jr., 1975). Este modelo fluvial se desenvolve próximo a costa, onde o baixo declive da superfície deposicional obriga o desenvolvimento de um padrão de drenagem distributária para dar vazão a elevada descarga proveniente de toda a bacia de captação. Como conseqüência, os rios são relativamente volumosos, lentos, retilíneos e dotados de elevada capacidade de transporte de carga sedimentar. Esta é predominantemente transportada como carga suspensa em razão da baixa competência dos distributários.

Embora este seja o modelo básico da sedimentação Morro Pelado, canais meandrantes puderam também ser reconhecidos pela típica granodecrescência ascendente e sucessão vertical de estruturas sedimentares, oriundas da variação vertical do regime de fluxo neste tipo de canal. A presença de canais meandrantes reflete flutuaçoes dos fatores básicos de controle da sedimentação fluvial.

\section{1 .5 Classificação genédica do Sistema Deltáico Serra do Espigão}

A abundância e diversidadè de complexos deltáicos modernos tem obrigado os estudiosos a elaborarem classificações para uma melhor sistemática de estudo e aplicação ao passado geológigo. Inúmeras classificações têm sido propostas baseadas na geomorfologia ou processos deposicionais básicos (Gulliver, 1899; Bates, 1953; Samojtov, 1956; Bernard, 1965 e Volker, 1966).

No presente estudo é adotada a classificação devida a Fisher e Brown (1972), que se baseia fundamentalmente na composição faciológica do sistema, especialmente na abundância relativa e seqüência de fácies.

A razão entre o nível de energia marinha relativamente ao volume de afluxo de terrígenos é, entre as diversas variáveis envolvidas na formaçăo de deltas, a que melhor se expressa em termos de composição de fácies de um sistema deltáico e, consequentemente, de particular valor na caracterização dos diversos tipos de deltas. Se o volume de aporte de sedimentos for elevado, relativamente ao nível de energia marinha, o sistema deltáico será constituido, predominantemente por fácies geradas por processos fluviais e classificado como delta construtivo; o moderno Mississipi é o exemplo clássico. Se por outro lado, o nível de energia for suficiente para retrabalhar todo o volu. me de afluxo de terrígenos, o sistema deltáico será constituido, predominantemente, por fácies geradas por processos sedimentares marinhos e classificados como ćestrutivo.

A forma de energia marinha envolvida determina os principais sub-tipos de deltas destrutivos. Em deltas destrutivos dominados por ondas, o principal depósito é uma série de cordðes litorâneos desenvolvidos nos flancos dos distribuitários; exemplos modernos incluem os deltas dos rios Ródano, Nilo, Dauúbio, Pó e os brasileiros São Francisco, Paraiba (Bacoccoli, 1971) e Doce (Bandeira Jr. et all., 1975). Em deltas destrutivos dominados por maré, os sedimentos são retrabalhados por correntes de maré, que produzem uma série de unidades arenosas, distribuidas radialmente a partir das desembocaduras dos distributários; entre os deltas modernos que se incluem neste tipo, citam-se os dos rios Mekong, Irrawady e do Golfo de Papua (Fisher et al., 1969). Embora os rios Amazonas e Orinoco, na América do Sul, desenvolvam estuários e não deltas, as condições hidrodinâmicas são semelhantes aos deltas destrutivos dominados por marés, resultando semelhantes fácies sedimentares.

$O$ istema deltáico Serra do Espigão embora apresente algumas carcterísticas de deltas construtivos (prodelta bem desenvolvido) e de deltas destrutivos dominados por ondas (arenitos litorâneos limpos e bem selecionados) é aqui classificado como destrutivo dominado por marés. Tal colocação se justifica pela abundância de barras de maré de grande extensão como os presentes na parte inferior da Serra do Espigáo e no Município de Mallet (Paraná). Igualmente, as argilas prodeltáicas, pela sua abundância em estruturas "flazer" evidencia a importância das correntes de maré na deposição destes sedimentos. Outra evidência provem da orientação das barras de maré, como indicada pelas seções estratigráficas, 
sempre alongadas no sentido sudeste para onde, se supõem, prevalecessem condiçð̃es marinhas mais francas.

\subsection{Planície de Maré Corumbataí}

A fácies de lamitos arroxeados é aqui interpretada como depositada em uma planície de maré, ora designada Planície de Maré Corumbataí. Sua ocorrência é registrada somente na regiăo norte e nordeste de São Paulo e sul de Goiás, em razão da limitação imposta em sua progradação sobre a plataforma Serra Alta pelos sedimentos prodeltáicos Serra do Espigão (fíg. 9). Na zona de transição, os sedimentos de ambos os sistemas se interdigitam evidenciando variaçð̃es de influência dos processos sedimentares de ambos os sistemas. Os sedimentos deltáicos, por possuirem um suprimento mais elevado, terminaram por se impor à planície de maré, recobrindo seus sedimentos e restrigindo a área de domínio de seus processos sedimentares. A espessura máxima da planície de maré Corumbataí é registrada no poço LI-1-SP (Lins $n^{0} 1$ ) onde atinge a 203 metros.

Planícies de maré se desenvolvem em regiões costeiras, planas, baixas e extensas onde a ação de ondas é desprezível, permitindo, consequentemente, a ação de correntes de maré. Tais condições são encontradas em estuários, lagunas, baías ou em áreas protegidas por ilhas de barreira ou deltas (Reineck e Singh, 1973). Seus dep6sitos resultam da ação combinada dos rios que trazem os sedimentos até o litoral e das correntes de maré que redistribuem esses sedimentos transportando a sua fração fina até os baixios onde são definitivamente depositados (Von Straaten e Kuenen, 1968).

Na planície de Maré Corumbataí, a fáceis de lamitos arroxeados representa os sedimentos argilosos dos baixios de maré (planície lamosa ou "mud flat") depositados na parte superior da zona de intermaré. Esta é a regiăo de mais baixa energia situando-se próximo ao nível de preamar. Lentes de arenito muito fino a síltico, muito argilosos com microestratificação cruzada presentes entre os lamitos arroxeados são resultantes da deposição na parte superior dos canais de maré.

Em planícies de maré estudadas no Recente (Luder, 1930; Hantzschell, 1939 in Medeiros et al., 1971) são descritas seqüências verticais com granodecrescência ascendente, caracterizada por sedimentos arenosos depositados na parte inferior e lamitos na parte superior da zona de intermaré. Na planície de maré Corumbataí os arenitos basais não se fazem presentes, atribuindo-se este fato ao tipo de suprimen- to terrígeno dominante. A principal contribuiçãose fez por correntés litorâneas e de maré que retrabalharam os sedimentos deltáicos Serra do Espigão em desenvolvimento ao sul. Como os sedimentos expostos ao retrabalhamento eram predominantemente siltes e argilas prodeltáicas, o suprimento à planície de maré careceu de frações arenosas. Suprimento terrígeno por rios que drenassem a área norte de São Paulo pode ter ocorrido, mas sua contribuição deve ter sido de menor importância.

\subsection{Plataforma Epinerítica Serra Alta}

A fácies de lamitos pretos é aqui interpretada como resultante da deposição de terrígenos em uma plataforma epinerítica dominada por um par epicontinental. Sua ocorrência é registrada em toda a Bacia do Paraná, a exceção do estados de Goiás, Mato Grosso e norte de Så Paulo. Mares epicontinentais diferem dos oceanos marginais pela ausência de mudanças significativas no declive da superfície deposicional. Não se desenvolvem os taludes continentais, como províncias geomorficas bem definidas, pela ausência de mudança brusca do declive na borda continental. A superfície deposicional é quase horizontal com um declive constante inferior a $0,1 \mathrm{~m} / \mathrm{km}$ e que se estende por grandes áreas. Embora de dimensð̃es restritas, exemplos modernos comparaveis aos do passado geol6gico são encontrados no Mar do Norte, Golfo Pérsico e Baía de Hudson (Stanley, 1969).

A fácies de lamitos pretos envolve um processo sedimentar, decantação de partículas em suspensão em ambiente marinho de baixa energia, típico das partes mais profundas de marés epicontinentais, correspondendo nos oceanos modernos à deposição no talude continental. Os autores discordam quanto ao mecanismo de transporte de terrígenos finos para esta regiăo, variando as opiniðes desde simples dispersão de partículas em suspensão, ação de correntes de maré ou correntes de turbidez de baixa densidade e baixa velocidade. Em qualquer das hipbteses o depósito resultante é em corpo tabular de grande extensâo lateral, constituido de siltes e argilas, com laminação paralela e muito rico em fosseis marinhos, o que se identifica perfeitamente com a fácies em estudo.

O mapa de tendência de espessura deste sistema deposicional (fig. 9) sugere que para sudeste o mar Serra Alta se estendia além dos atuais limites da bacia do Paraná; para norte e noroeste a isópaca zero se define na regiăo norte de São Paulo e sul de Goiás. Esta distribuição e tendência de espessuras sugere um mar em forma de golfo, aberto para sudeste, cujos limites interiores atingiam a região sul de Mato Grosso e Goiás e norte de São Paulo.

\section{MODELO DE SEDIMENTAÇ ̃̃O}

Com base na analogia com modelos de sedimentação do Recente, interpreta-se o Grupo Passa Dois, exclusive Formação Irati, como resultado do assoreamento de um mar epicontinental por três sistemas deposicionais penecontemporâneos: plataforma epinerítica Serra Alta, sistema deltáico Serra do Espigão e planície de maré Corumbataí (fig. 10). Estes, assumiram importâncias variáveis, geográfica e temporalmente, na evolução da Bacia do Paraná durante o Permiano Superior.

O sistema de plataforma Serra Alta, responsável pela fácies de lamitos pretos, representa a sedimentação marinha em condiçð̃es de plataforma epinerítica. A extensão deste sistema sugere um mar em forma de golfo, aberto para sudeste e com limites interiores no norte de Săo Paulo e sul de Goiás e Mato Grosso.

Progradante sobre o golfo Serra Alta a partir do sul de Mato Grosso, desenvolveu-se o sistema deltáico Serra do Espigåo, constituida por um conjunto de deltas destrutivos por marés. As fáceis de lamitos cinza Terezina e arenitos esverdeados Serrinha representam os sedimentos depositados em condições sub-aquosas no prodelta e frente deltáica, respectivamente. Barras de desembocadura e de maré constituem os depósitos da frente deltáica, cuja distinção é feita através de suas relações faciologicas. As fácies de arenitos lenticulares e lamitos avermelhados são resultantes de sedimentação fluvial na planície deltáica. São identificados neste ambiente depositos de canal distributário, canal meandrante, canal abandonado, "crevasses splays", diques marginais e de planície de inundação. A drenagem alimentadora dos deltas era constituída por rios de elevada descarga, baixo declive e com carga sedimentar transportada, predominantemente, em suspensão.

A classificação como delta destrutivo dominado por marés se justifica pela composição faciológica, onde as correntes de mare representaram o principal processo sedimentar deposicional dos sedimentos subaquosos.

Em função da proteção oferecida pelos deltas, que desempenharam a função de barreira à ação de ondas, desen volveu-se, contemporaneamente, no litoral norte deste golfo, a planície de maré Corumbataí. A fácies de lamitos arroxeados de São Paulo representa os 
sedimentos de baixios de maré, depositados na parte superior da zona de intermaré. A progradação de norte para o sul deste sistema não ultrapassou os limites dos estados de São Paulo e Goiás. As condições climáticas reinantes à época caracterizavam-se por temperaturas elevadas e alta pluviosidade responsáveis pelo padrão de canal retilíneo da planície deltáica, cores avermelhadas de seus e dos depósitos da planície de maré, além do desenvolvimento de unidades destrutivas de natureza carbonática biodetrítica em condições subaquosas.

Esta paisagem geomórfica era dominada por um quadro tectônico caracterizado por lenta e generalizada subsidência, não se constatando nenhuma evidência de falhamentos singenéticos. A região do Alto de Ponta Grossa caracterizava-se por subsidência mais acentuada.

$\mathrm{O}$ assoreamento deste mar epicontinental se processou em condições de elevado suprimento relativamente a subsidência, resultando um empilhamento progradacional. Como conseqüência, os sedimentos dos sistemas litorâneos, deltas Serra do Espigão e planície de maré Corumbataí, se sobrepuseram aos sedimentos da plataforma Serra Alta nos estados do sul e São Paulo respectivamente. A extensão da planície fluvial aos estados sulinos finaliza o ciclo de sedimentação do Grupo Passa Dois, produzindo a clássica sucessão vertical das unidades litoestratigráficas formais.

\section{CONSIDERAÇÃO FINAIS}

O grande número de pesquisas realizadas em sedimentos recentes, particularmente nestas três últimas décadas, consagrou o uso de modelos de sedimentação em análises estratigráficas. Estes estudos permitiram uma melhor compreensão da relação processo sedimentar - fácies nos ambientes de cada província guomórfica de sedimentação

BACOCCOLI, G. - 1971 - Os deltas marinhos holocênicos brasileiros: uma tentativa de classificação. Bol. Tec. PETROBRÁS, vol 14 no $1 / 2$ 14
BANDEIRA JR., A.N.: PETRI, S. e SUGUIO, K. - 1975 -Projeto Rio Doce (Relatório Final) PETROBRÁS-USP

BATES, C.C. - 1953 - Rational Theory of delta formation: Bull. Amerc. Assoc. Petrol. Geol. vol. 37 pp. $2119-2162$

BERNARD, H.A. - 1965 - A resume of rive delta types (abs.): Bull, Amer. Assoc. Petrol. Geol., vol. 49, pp. 334-335.

DAEMON, R.F. e QUADROS, L.P. - 1969 Bioestratigrafia e Palinologia do Paleozóico superior da Bacia do Paraná - PETROBRAS /DESUL, rel. int. no 384 .

EMERY, K.O. - 1968 - Relict sediments ou moderna. Como decorrência, parâmetros mais objetivos de extrapolação ao passado ficaram melhor definidos.

Entre as províncias modernas de sedimentação, os deltas mereceram sempre uma maior atenção dos pesquisadores dada à sua potencialidade em recursos naturais. Petróleo, carvåo, minerais radioativos, argilas industriais tem sido frequentemente encontrados associados aos diferentes ambientes do complexo deltáico.

Um dos aspectos mais interessantes levantado pelos especialistas refere-se d aparente contradição entre a abundância relativa de sedimentos deltáicos modernos e a relativa escassez no registro geológico. Atualmente aproximadamente $50 \%$ dos sedimentos terrígenos em 'ormação pertencem a esta província. Evidências de ordem tectônica indicam que não existe razão para que no registro geológico sua freqüência seja menor. O Autor atribui esta contradição à problemas de interpretação, para o qual concorrem dois fatores primordiais: dimensões de um depósito deltáico e modelo de comparação.

Ambos os fatores são importantes para o reconhecimento de deltas no registro geológico, mas a escala envolvida é de maior relevância. O conjunto de deltas Serra do Espigão teria uma extensão da ordem de 500 quilômetros e espessura de 1200 metros aproximadamente. Seriam estas dimensões compatíveis com uma seqüência deltáica? Para responder esta questão é necessário compreender a incrível taxa de crescimento envolvida em deltas. A tabela abaixo, extraída de Smith (1966) in
Reineck e Singh (op cit) fornece alguns exemplos.

Depreende-se da análise destes dados que a extensão de uma seqüência deltáica depende, entre outros fatores, da morfologia costeira. O elevado suprimento e a alta taxa de crescimento produzirá o assoreamento do sítio deposicional sejam quais forem suas dimensões ou seu grau de subsidência. Acrescentando, ainda, que o sistema deltáico Serra do Espigão é composto por diversas seqüências deltáicas desenvolvidas por vários distributários em vários ciclos deltáicos conclui-se que suas dimensões são perfeitamente comnatíveis com os modelos recentes.

$\mathrm{O}$ segundo fator a considerar no reconhecimento de deltas no registro geol6gico relaciona-se com o modelo moderno de comparação. A extensa lista de trabalhos publicadas sobre o delta do Mississipi tornou-o um modelo por excelência. Entretanto, o mesmo representa apenas um tipo específico desenvolvido e1:ı condições hidrodinâmicas extremamente favoráveis. A grande maioria dos deltas modernos de todo o mundo são destrutivos, seja por ondas, como os brasileiros, seja por marés. Em deltas destrutivos as fácies subaquosas por serem depositadas por processos sedimentares marinhos, apresentam-se com características semelhantes a outros tipos de sedimentos marinhos. Este fato aliado à diferença de composição, geometria, relaçסes faciológicas, associação de estruturas sedimentares, etc., entre possíveis seqüências deltáicas e o delta do Rio Mississipi justifica a dificuldade de seu reconhecimento no registro geológico.

\begin{tabular}{|l|c|c|}
\hline Delta & $\begin{array}{c}\text { Estensão subaérea } \\
\mathrm{Km}^{2} \cdot 10^{3}\end{array}$ & $\begin{array}{c}\text { Taxa de crescimento } \\
\text { M/ano }\end{array}$ \\
\hline Pó & 14 & $26-61$ \\
\hline Irrawady & 31 & $46-61$ \\
\hline Mekong & 52 & 61 \\
\hline Mississipi & 29 & 91 \\
\hline Yellow Plain & 127 & 268 \\
\hline
\end{tabular}

\section{BIBLIOGRAFIA}

continental ou - shelues of the world: Am Assoc. Petrol. Geol. Bull., v 52, pp. 445-464.

FISCHER, W.L. et all. - 1969 - Delta systems in the exploration for oil and gas - a research colloquium. Univ. Texas. Bur. Econ. Geology: spec. publ., $212 \mathrm{p}$

FISCHER, W.L. and BROWN Jr., L.F. - 1972 Clastic depositional systems - A genetic approach to fácies analysis. Univ. Texas. Bur. Econ. Geology, 211 p.

FISCHER, W.L. and McGOWEN, J.H: - 1967 - Depositional systems in the Wilocx Group of Texas and their relationaship to occurrence of oil and gars: Gulf Coast Assoc. Geological Societies. Trans. v. 17 p. 105-125

FISCHER, W.L. and SCOTT, A.J. - inédito Modelos da Sedimentação fluvial, 44 p.

FULFARO, V.J. - 1971 - A evolução tectônica e paleogeográfica da Bacia Sedimentar do Paraná pela "Trend Surface Analysis". eescusp. Bol. Geologia ${ }^{\circ} 14$.

FULFARO, V.J. SAAD, A.R.; CAMPAGNA. W.A. e CANUTO, J.E. - 1978 - Consideraçôes sobre a gênese da Formação Estrada Nova (P) da Bacia do Paraná. Anais do XXX Cong. Brasil. Geologia. Soc. Bras. Geologia. Recife.

GAMA Jr., E. - 1975 - Transporte e deposição de sedimentos em ambientes fluviais. Seminário de Pós-Graduação USP Inédito.

GULLIVER, F.P. - Sharline topography: Proc Amer. Acad. Arts. Sci., v. 34, p. 151-258.

LANDIM, P.M.B. - 1967 - O Grupo Passa Dois (P) na bacia do rio Corumbatai (SP) Dep. Nac. Prod. Min. Div. Geol. e Mineral. Bol. 252. 
MEDEIROS, R.: SCHALLER, H. A FRIEDMANN, G.M. - 1971 - Fácies Sedimentares: análise e critérios de reconhecimento de ambientes deposicionais. Ciênc. Técnica e Petróleo. PETROBRÁS-CENPES, 123 p.

MENDES, J.C. - 1967 - The Passa Dois Group(the brazilian partion of the Paraná Basin). Brazilian contriuution to the Int. Symposium on the Gondwana stratigraphy and paleontology. pp. 119-162. Curitiba.

MENDES, J.C. e FULFARO, V.J. - 1966 - As camadas gondwâncias 'no nordeste do Paraná. Bol. Soc. Bras. Geol., v. $15, n^{\circ} 4$, pp. 29 42.
MUHLMANN H. et all - 1974 - Revisão estratigráfica da Bacia do Paraná. PETROBRÁS -DE-SUL, rel. $\mathrm{n}^{\circ} 444$. Inédito.

NORTHEFLEET, A. et all. - 1969 - Reavaliação dos dados geológicos da Bacia do Paraná. Bol. Tec. PETROBRÁS, v, 12 n 3 pp. 291-346.

REINECK, H.E. and SINGH, I.B. - 1973 Depositional Sedimentary Environments with reference to terrigenous clastics. SpringerVerlarg. Berlin, 439 p.

SOARES, PC. - 1972 - Estruturas estromatoli- ticas na Formação Estrada Nova (Permiano) no estado de São Paulo, XX|VI Cong. Bras. de Geologia. Soc. Bras. Geol. Belém.

SOARES, P.C.; LANDIM, P.M.B. e FULFARO, VJ - 1974 - Avaliação preliminar da evolução geotectônica das Bacias intracratônicas brasileiras: XXVII Congr. Bras, Geol, Resum. Com., Bol., 1, pp. 706-710 (ahs).

STANLEY, D.J. - 1969 - The new concepts of Continental margin sedimentation. AGI short Course Lecture Notes, Philadelphi $a$.

WALTHER, S. - 1894 - Lithogenesis der Gegenwart. Beo-bachtungeruber die Bildreng der Gesteine an der heutiger Erdoberflache, p. 535-1055. Jena: Verlag Gustave Fischer.

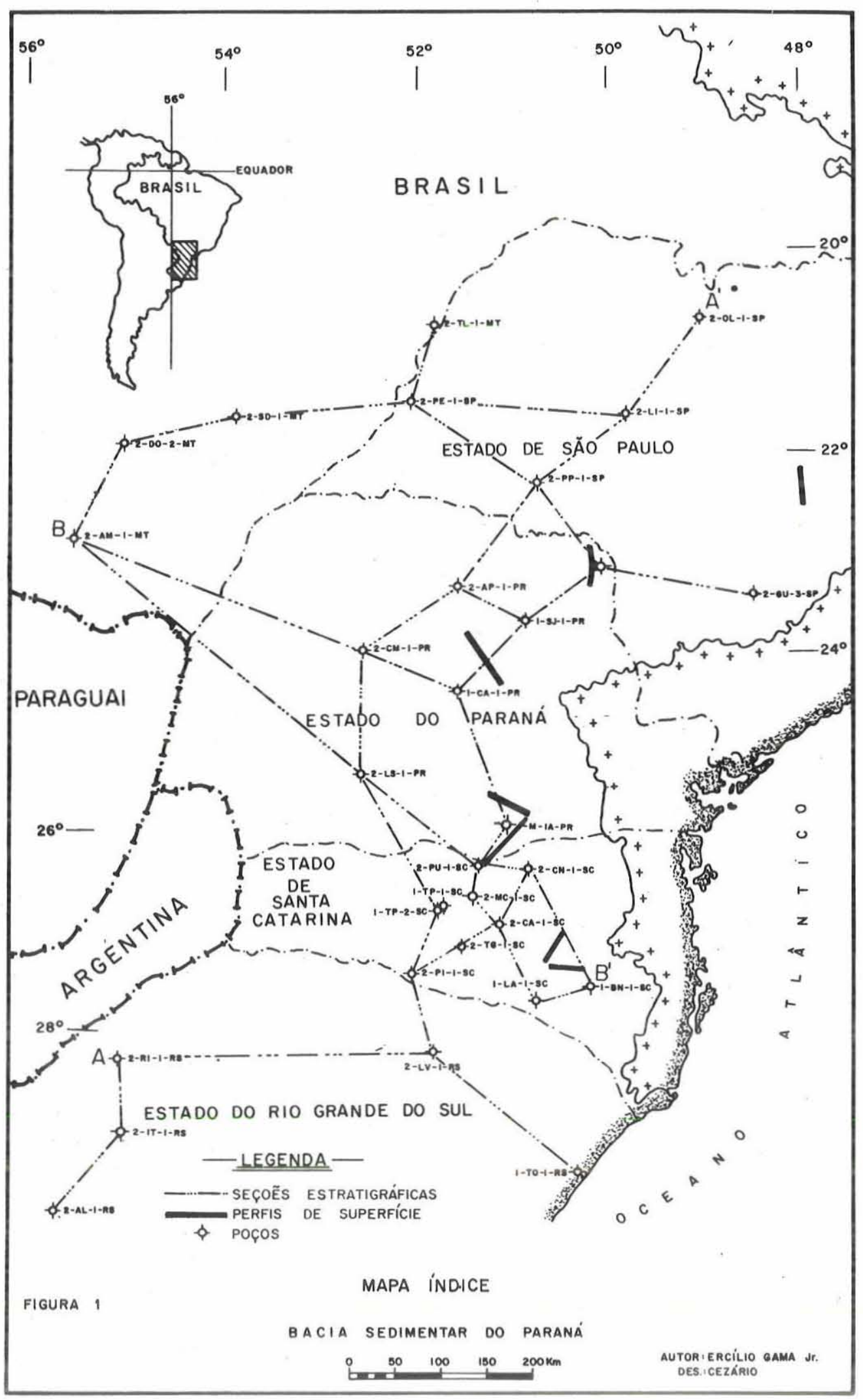




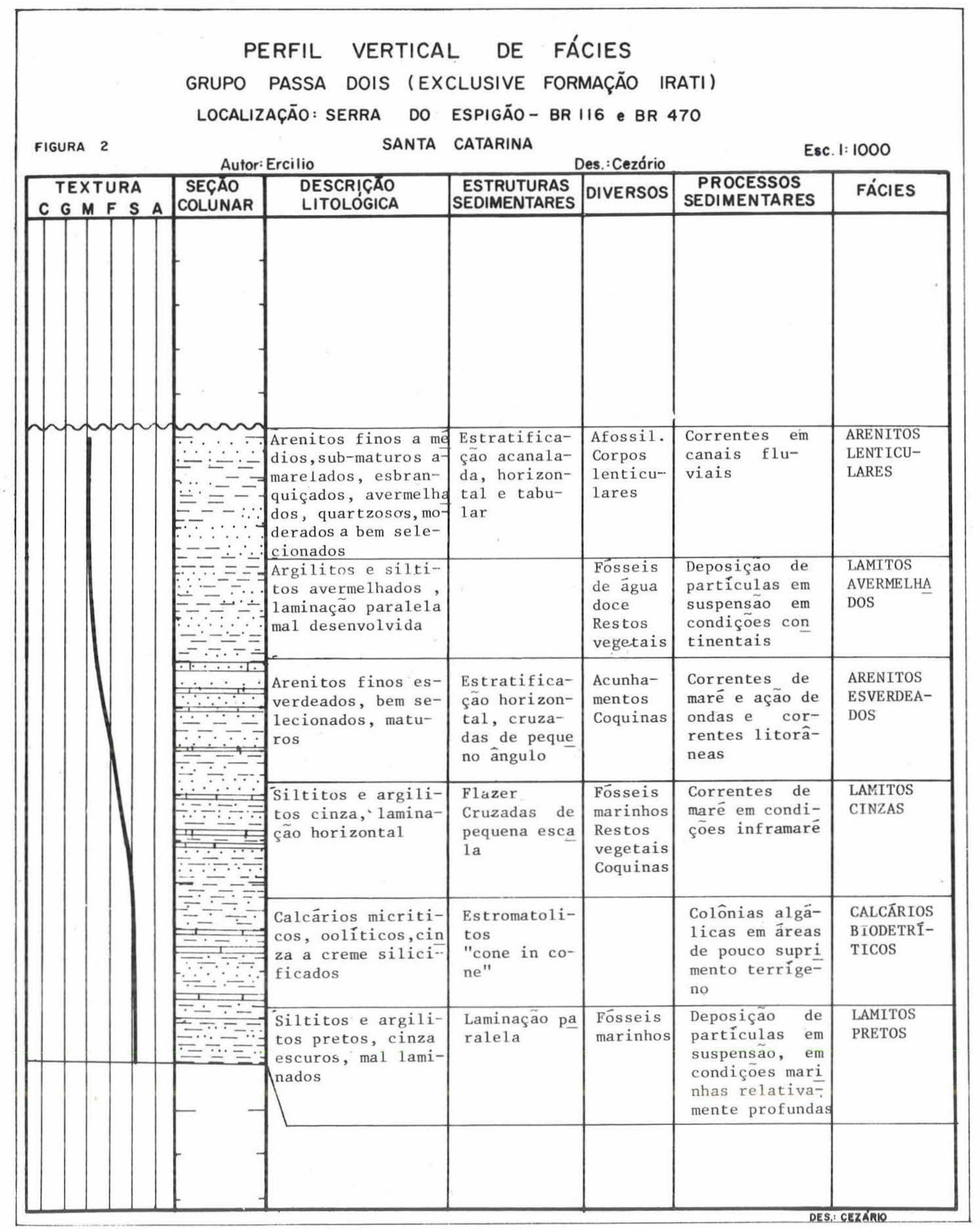




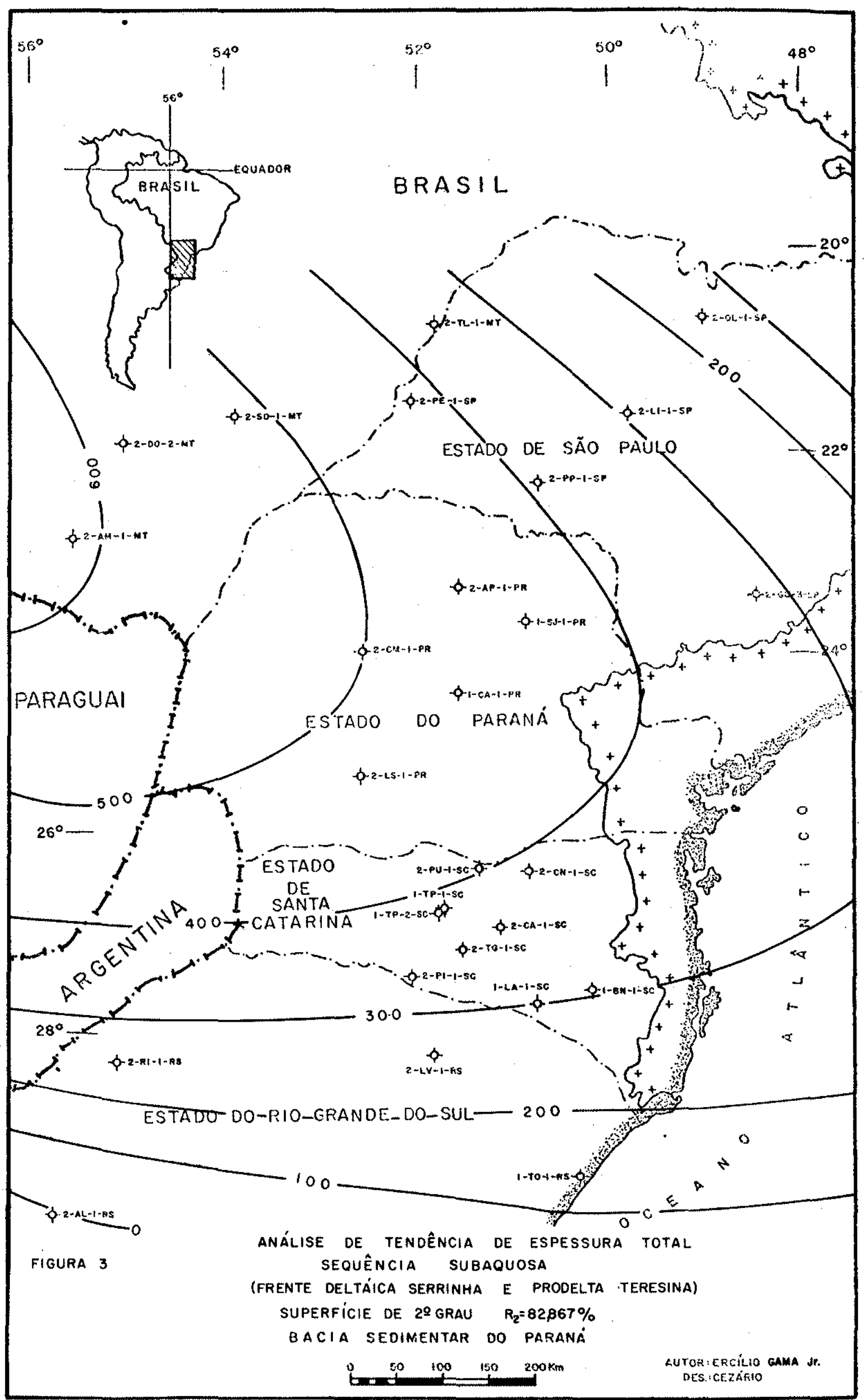




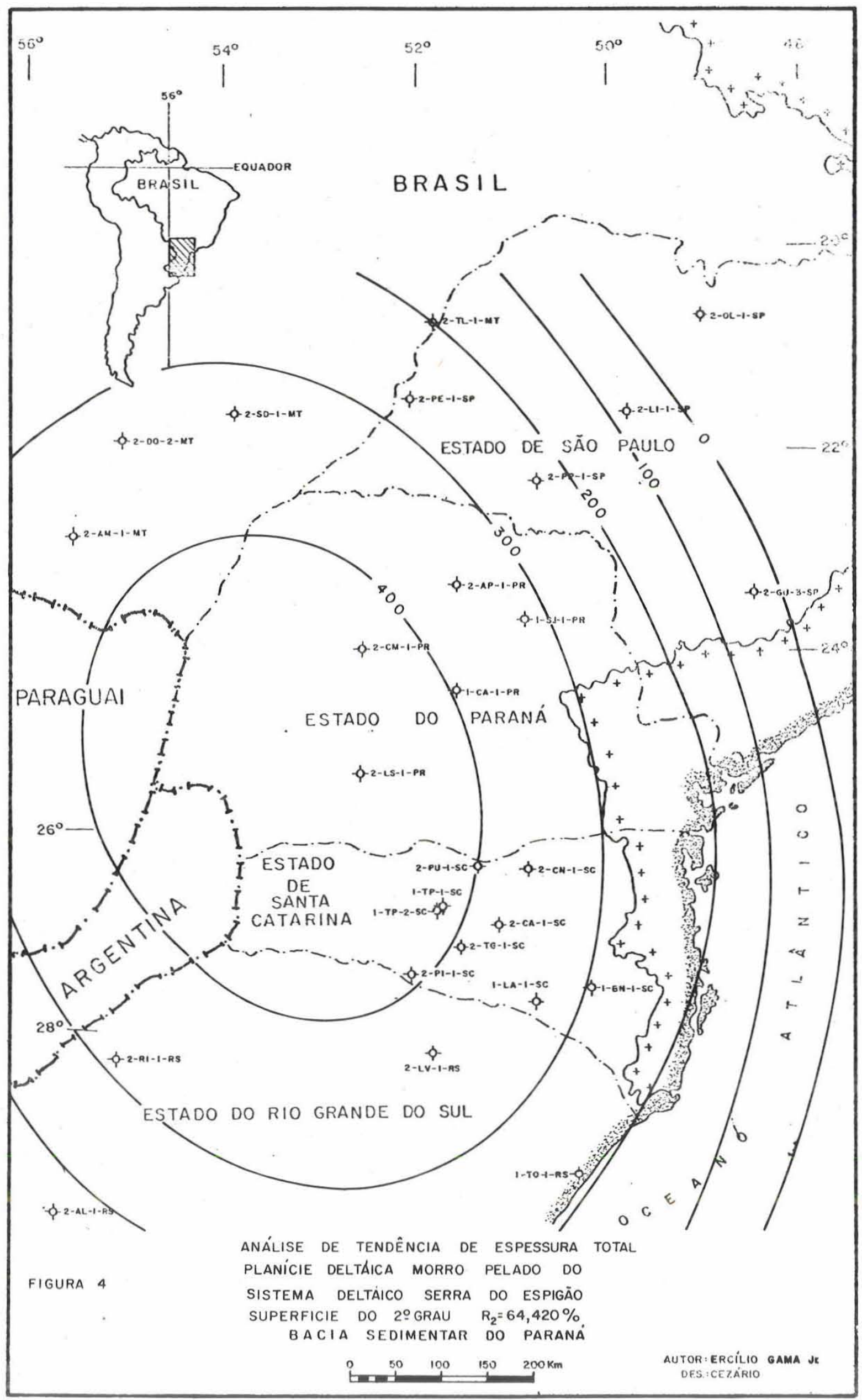




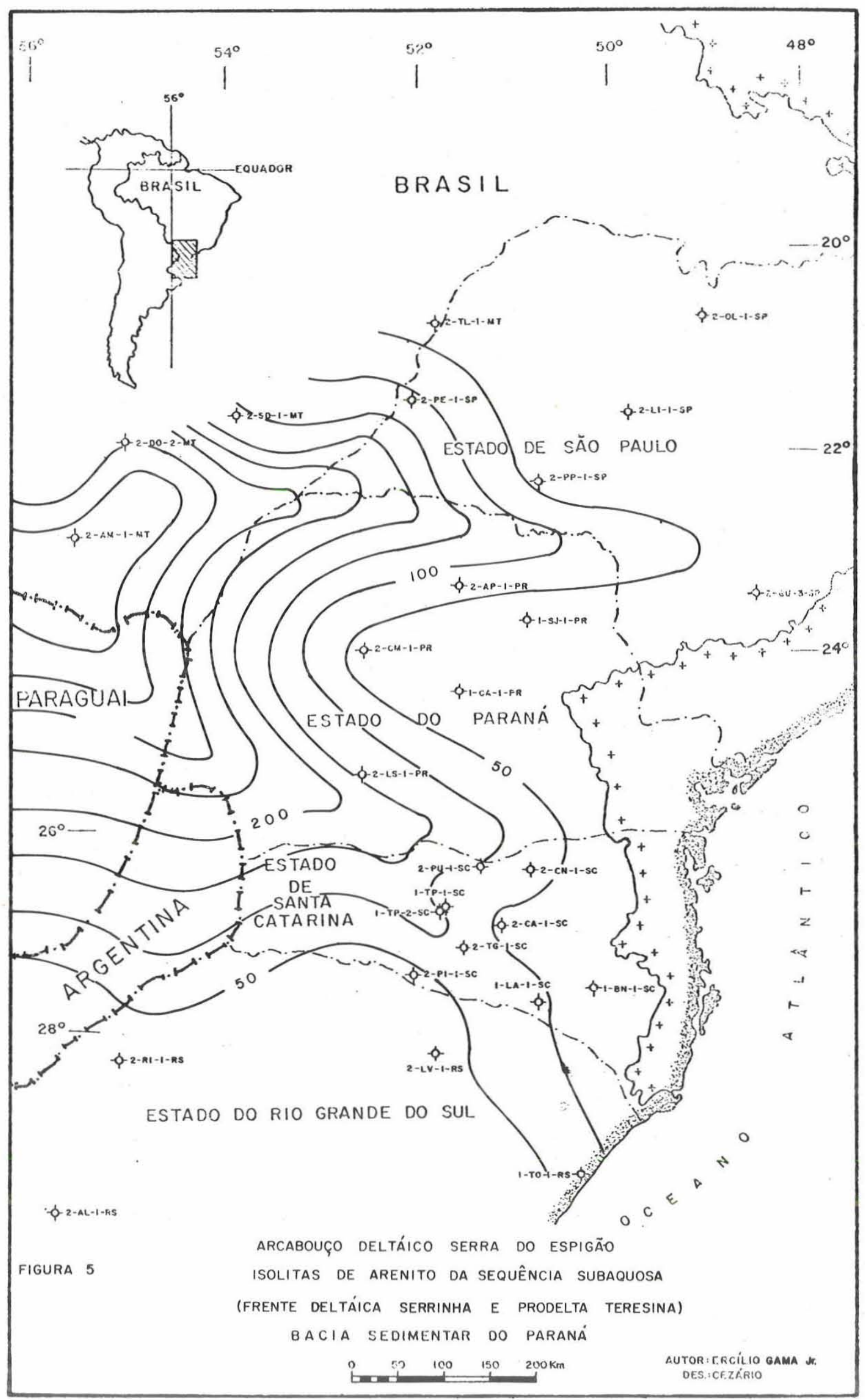




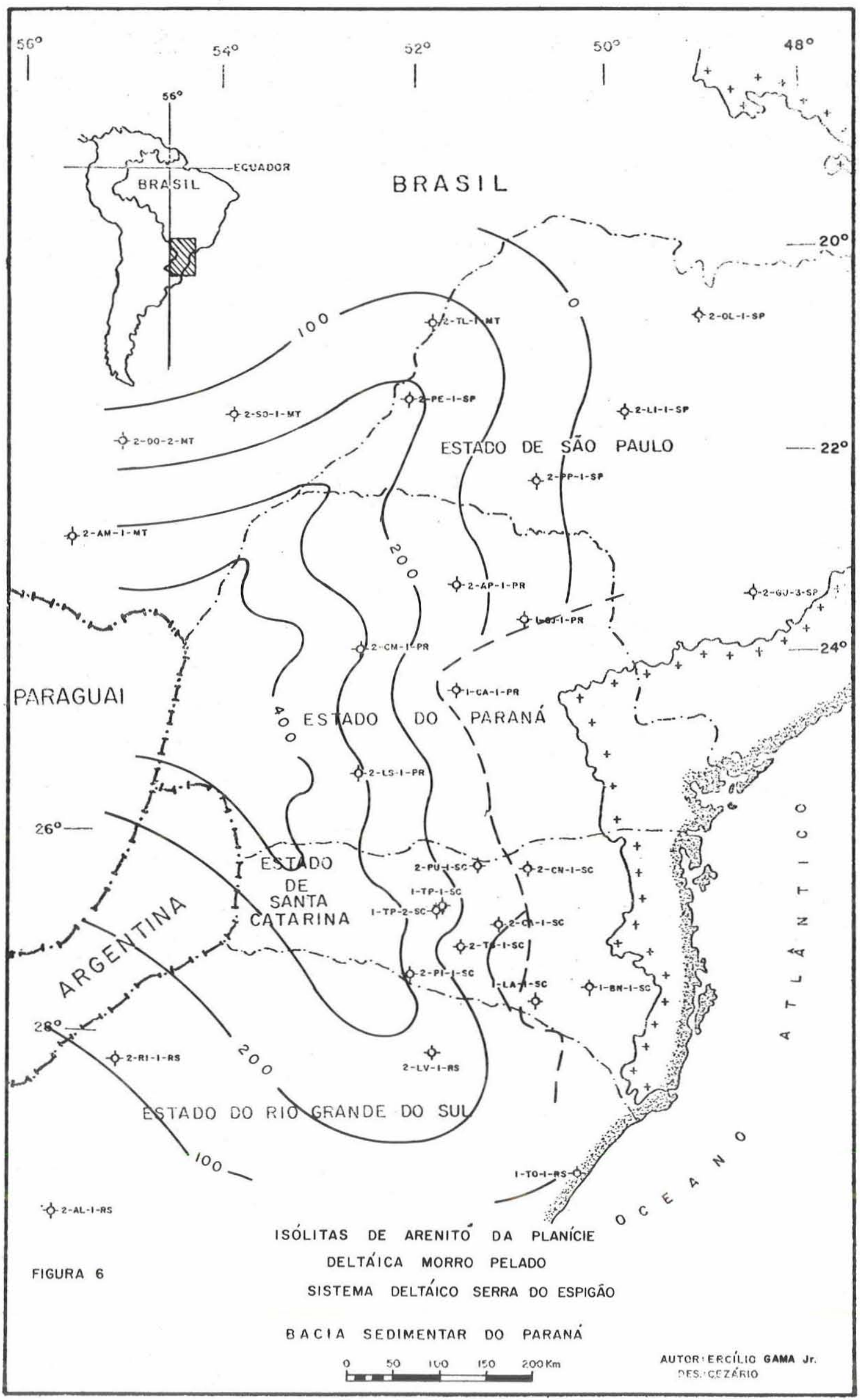



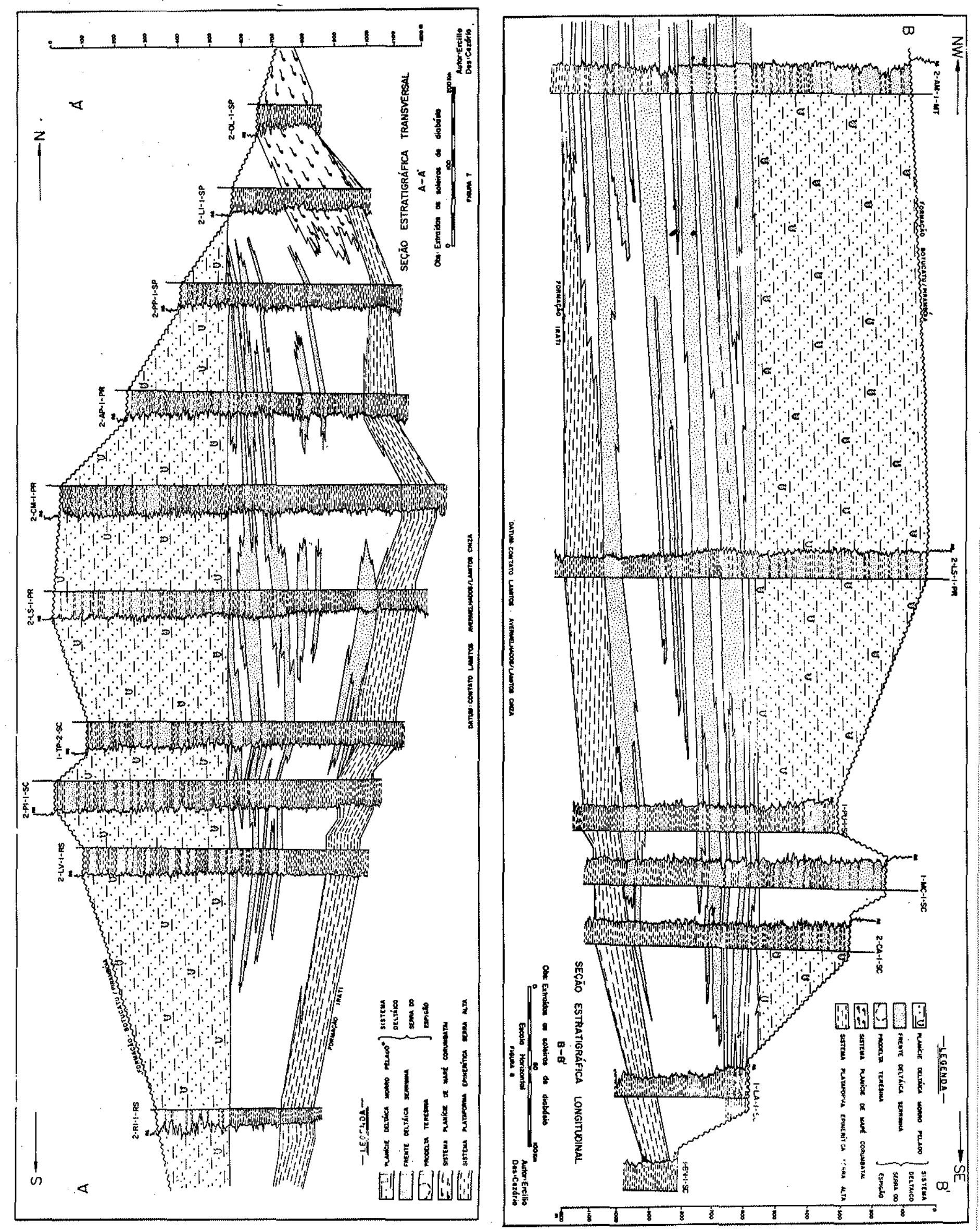


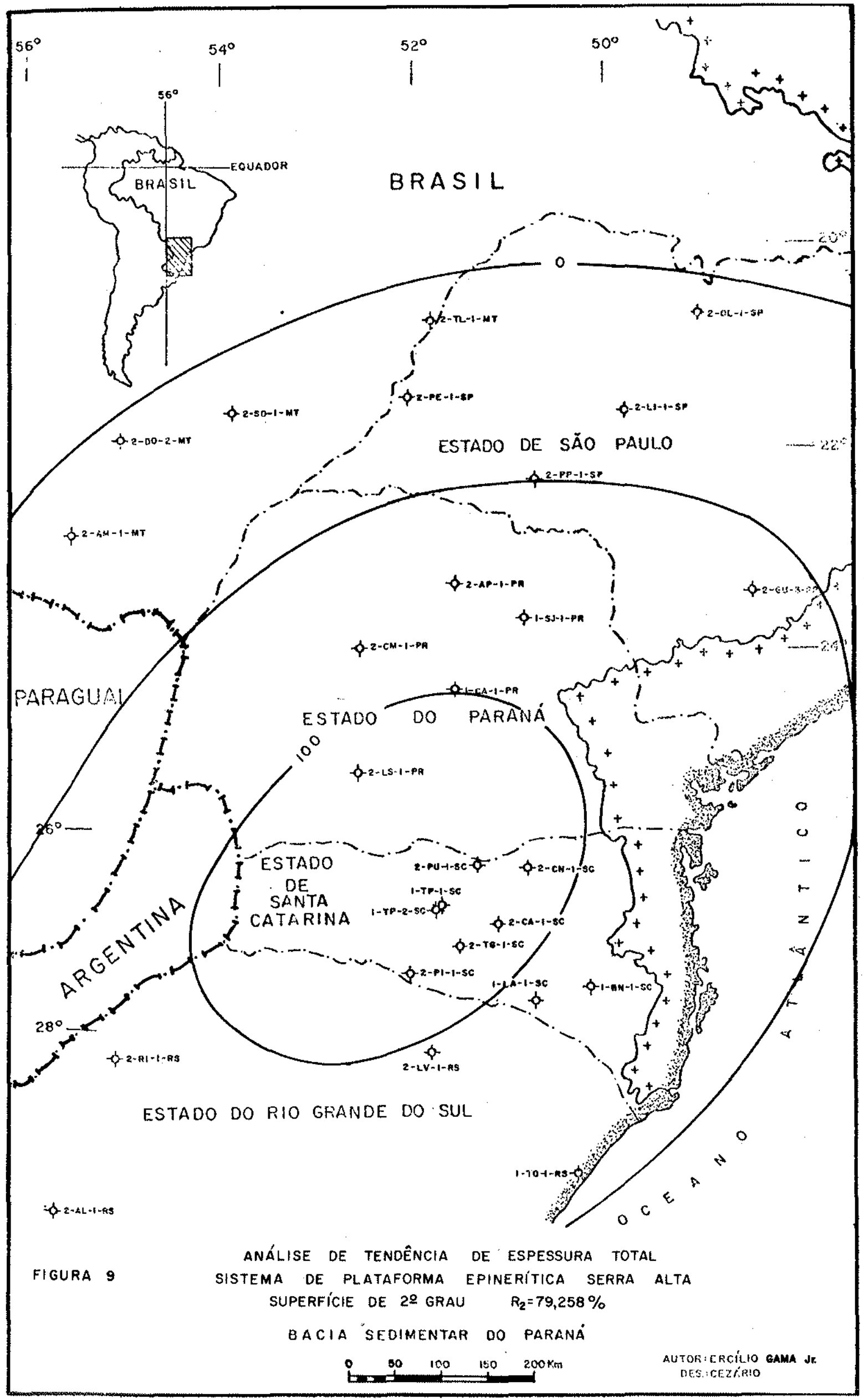




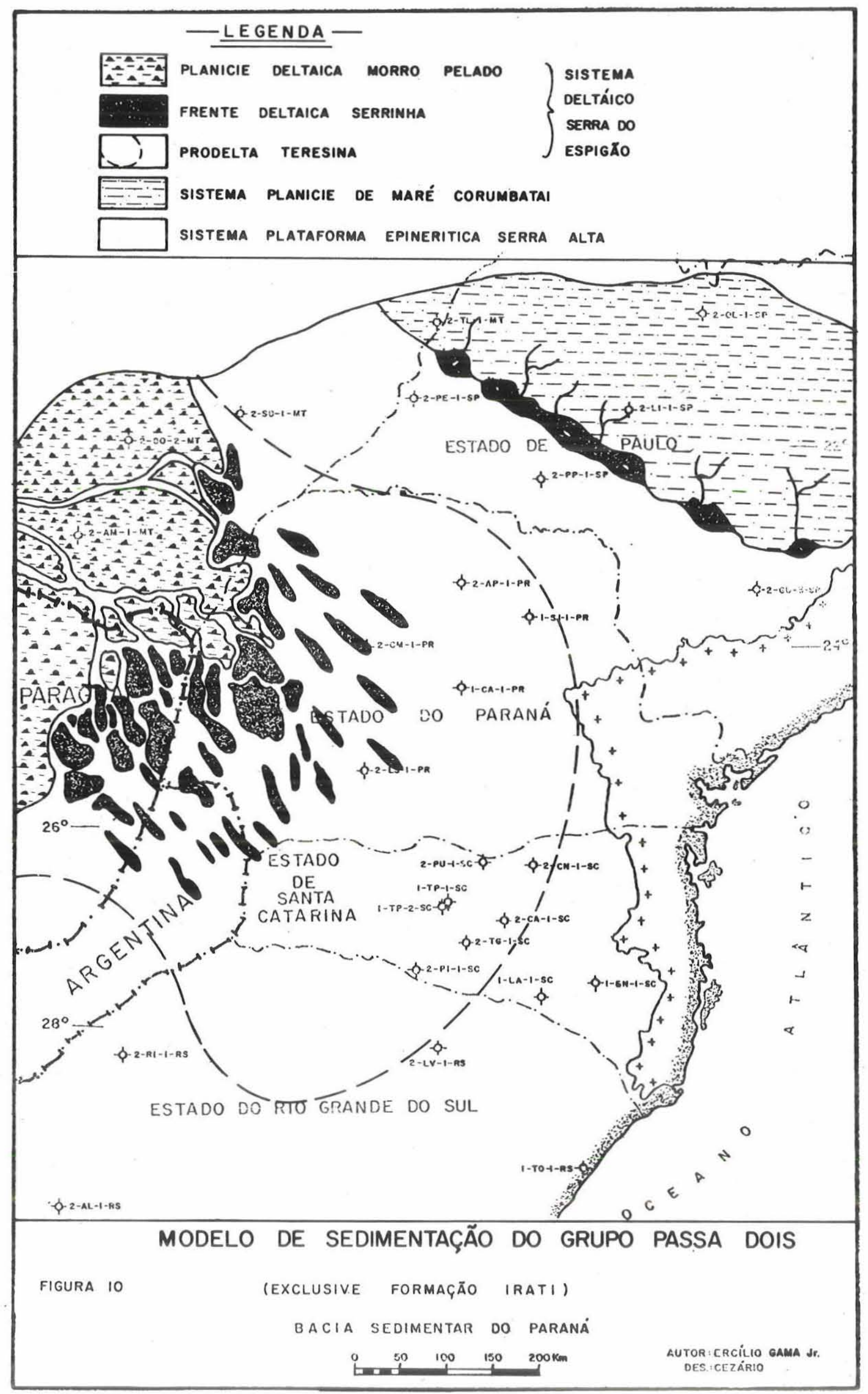

